\title{
História dos livros e das edições didáticas: sobre o estado da arte*
}

\author{
Alain Choppin**
}

Após ter sido negligenciado, tanto pelos historiadores quanto pelos bibliógrafos, os livros didáticos vêm suscitando um vivo interesse entre os pesquisadores de uns trinta anos para cá. Desde então, a história dos livros e das edições didáticas passou a constituir um domínio de pesquisa em pleno desenvolvimento, em um número cada vez maior de países, e seria pouco realista pretender traçar um estado da arte exaustivo sobre o que foi feito e escrito e, mais ainda, do que se pesquisa e se escreve atualmente pelo mundo. Nosso objetivo é abarcar, limitando-nos necessariamente a alguns exemplos, as principais problemáticas identificadas e temas abordados pela pesquisa histórica sobre os livros e edições didáticas, destacando as tendências mais marcantes e as possíveis perspectivas de evolução.

\section{Dificuldades e limites da proposta}

Se, até onde sabemos, nenhuma tentativa como essa chegou a ser realizada, ${ }^{1}$ é porque ela se defronta com uma série de dificuldades que certamente limitam seu alcance, sem diminuir, entretanto, seu interesse.

A primeira dificuldade relaciona-se à própria definição do objeto, o que se traduz muito bem na diversidade do vocabulário e na instabilidade dos usos lexicais. Na maioria das línguas, o "livro didático" é designado de inúmeras maneiras, e nem sempre é possível explicitar as características específicas que podem estar relacionadas a cada uma das denominações, tanto mais que as palavras quase sempre sobrevivem àquilo que elas designaram por um determinado tempo. Inversamente, a utilização de uma mesma palavra não se refere sempre a um mesmo objeto, e a perspectiva diacrônica (que se desenvolve concomitantemente à evolução do léxico) aumen- ta ainda mais essas ambigüidades. Alguns pesquisadores se esforçaram em esclarecer essas questões e estabelecer tipologias, ${ }^{2}$ mas constata-se que a maior parte deles se omite em definir, mesmo que sucintamente, seu objeto de estudo.

A segunda dificuldade diz respeito ao caráter recente desse campo de pesquisa: as obras de síntese ainda são raras e não abrangem toda a produção didática nem todos os períodos; ${ }^{3}$ a produção científica que trata especificamente da história da literatura e das edições didáticas constitui-se essencialmente de artigos (geralmente capítulos de livros) publicados em revistas ou livros (de uns tempos para cá também em sites) onde, na maior par-

* Este artigo se originou da comunicação feita no XXII ${ }^{\circ}$ Congresso do ISHEE em Alcalá, Espanha e foi publicado na revista Paedagogica Histórica v. 38, n. 1, 2002 , p.21-49. Tradução de Maria Adriana C. Cappello. ** Alain Choppin é pesquisador do Service d'histoire de l'éducation do Institut National de Recherche Pédagogique- INRP- URA CNRS 1937, França.

1. Apenas umas trinta páginas (em 455) são dedicadas às pesquisas históricas em Egil Børre Johnsen, Textbooks in the kaleidoscope: a critical survey of literature and research on educational texts (Oslo, 1993).

2. Sobre esses aspectos ver, notadamente: Hide Coeckelberghs, "Das Schulbuch als Quelle der Geschichtsforschung. Methodologische Überlegungen", Internationales Jahrbuch für Geschichts-und Geographieunterricht, XVIII (1977-1978), p. 7-29; Alain Choppin, "Les manuels scolaires: une approche globale", Histoire de l'éducation, IX (1980), p. 1-25; David Hamilton, "What's is a textbook?", Paradigm, III (1990), p. 58; Keith Hoskin, "The textbook: further moves toward a definition", Paradigm, III (1990), p. 8-11; Agustín Escolano Benito, "Tipologia de libros y gêneros textuales en los manuales de la escuela traditional", in Alejandro Tiana Ferrer (dir.), El Livro escolar, reflejo de intenciones políticas e influencias pedagógicas (Madrid, 2000), p. 439-450.

3. Citaremos, notadamente, para o Japão, Tomitaro Karasawa, Kyôkasho no rekishi — kyôkasho to nihonjin no keisei [História do livro didático — 0 livro didático e a formação dos japoneses] (Tókio, 1956); para os Estados Unidos, Charles H. Carpenter, History of American schoolbooks (Philadelphia, 1963); para a Coréia, Chong Kuk Lee, Han Kuk Kyo Kwa So [Os livros didáticos da Coréia] (Seul, 1991); para a Nova Zelândia, Hugh Price, School books published in New Zeland to 1960 (Palmerston North, 1992); para a França, Alain Choppin, Les manuels scolaires: histoire et actualité (Paris, 1992); para o Brasil, Circe Maria Fernandes Bittencourt, Livro didático e conhecimento histórico: uma história do saber escolar(Tese de doutorado, São Paulo, 1993); para a Espanha, Augustín Escolano Benito (Dir.), Historia ilustrada del libro escolar em España, 2 vol. (Madri, 1997-1998); para a Itália, Giorgio Chiosso (org.) II Libro per la scuola tra Sette e Ottocento (Brescia, 2000). 
te das vezes, ninguém pensaria em procurá-los; ainda é preciso alertar que fazer um recenseamento dessa produção partindo apenas de títulos de artigos ou de livros mostra-se fonte de desilusões e de incertezas. Tivemos essa experiência ao estabelecer o estado da arte da produção científica francesa. ${ }^{4}$ Também Paul Aubin constatou os mesmos problemas, quando se propôs a fazer o recenseamento da produção historiográfica quebequense. ${ }^{5}$

Uma outra dificuldade refere-se à recente inflação de publicações que se interessam pelos livros didáticos: a consulta do catálogo informatizado da Biblioteca do Congresso, por exemplo, ou de bases de dados especializadas em educação, como a ERIC, fornece, apenas para os termos textbook e textbooks, milhares de referências sem, no entanto, significar que esgotam o assunto. Esse crescimento quantitativo da produção científica observa-se também em relação aos estudos de antigos manuais escolares, abordados sob diversas perspectivas. A análise da produção histórica mundial desses últimos quarenta anos não apenas confirma como reforça as conclusões da análise bibliométrica da produção francesa que haviamos realizado. ${ }^{6}$ Constatamos, então, que mais de três quartos da produção científica têm menos de vinte anos e que 45\% têm menos de dez; em relação às 2 mil referências que temos hoje processadas em banco de dados, referentes a aproximadamente cinqüenta países, corpus sobre o qual nos apoiamos neste artigo, três quartos são posteriores a 1980 e mais da metade após $1990 .^{7}$

Uma última dificuldade, igualmente grave, é a barreira da língua. Mesmo que as principais revistas especializadas forneçam, na maioria das vezes em inglês, resumos de publicações redigidas em línguas pouco conhecidas por grande parte dos pesquisadores, isto não substitui a leitura do original. Além disso, esses inventários referem-se a um pequeno número de publicações e não levam em conta os artigos, que constituem o essencial da produção científica na área.

Temos, portanto, plena consciência que esse inventário é certamente bastante incomple- to, e a própria referência aos documentos pertinentes não é fácil; o conhecimento que temos do que é escrito no exterior sobre a história do livro didático dá-se de forma bastante parcial e aleatória, uma vez que há carências de bibliografias especializadas. A bibliografia produzida anualmente pelo George-Eckert-Institut de Brunswick, na Alemanha, é certamente a mais completa, mas, se ela apresenta um número bastante grande de publicações, produzidas ou não segundo uma perspectiva histórica, estas se referem apenas a livros didáticos de leitura e de ciências sociais. ${ }^{8}$ No que se refere às revistas consagradas à história da educação ou à história do livro, que é o nosso objeto, freqüentemente apresentam o problema inverso. Com exceção da preciosa revista Paradigm, publicada pelo Textbook Colloquium, ${ }^{9}$ as revistas cobrem um amplo domínio e, se fornecem resumos ou apreciações críticas, cuja leitura pode mostrar-se bastante proveitosa, raramente trazem bibliografias sistemáticas que contenham index. ${ }^{10}$ A experiência mostra que

4. Alain Choppin, Les manuels em France de 1789 à nous et recherches (Paris, 1995); Id., "L'Histoire de l'édition en France aux XIXe et XXe siècles: bilan et perspectives", Annali di storia dell'educazione e delle istituzioni scolastiche, IV (1997), p. 9-32.

5. Paul Aubin, Le Manuel scolaire dans l'historiographie québécoise (Sherbrooke, 1997).

6. Alain Choppin, "L'Histoire des manuels scolaires: um bilan bibliométrique de la recherche française" in: Alain Choppin (dir.), Manuels scolaires: Etats et sociétés, XIXe-XXe siècles, [=Histoire de l'education, LVIII], (1993), p. 165-185.

7. Esse corpus, que brevemente estará disponível via internet, foi constituído a partir de três fontes: apuração sistemática das principais revistas especializadas em história da educação desde o início dos anos 1960; pesquisas bibliográficas desenvolvidas de forma sistemática nos catálogos da maior parte das bibliotecas nacionais e nos bancos de dados especializados na área da educação; levantamento de bibliografias e notas de rodapé de várias centenas de artigos, contribuições ou livros. Esse corpus seguramente não é exaustivo, mas, levando em conta o aparecimento freqüente das mesmas referências bibliográficas nas mais variadas fontes, parece-nos que reflete com bastante fidelidade as características e a evolução da produção científica contemporânea. Em relação às pesquisas em andamento e ainda não publicadas, gostaríamos de agradecer a todos os colegas estrangeiros que gentilmente nos forneceram as informações de que dispunham.

8. Internationale Schulbuchforschung. Zeitschrift des Georg-EckertIntitus. Ver <http: // www.gei.de / geihome.htm>.

9. Ver <http: // www.open.ac.uk / OU / Academic /Arts / TEXTCOLL>

10. Citamos, no entanto, a revista Paedagogica Historica que apresentou, de 1961 a 1985, uma bibliografia internacional dedicada às publicações relativas à história de educação, como também a revista Histoire de l'éducation, que publica todo ano, desde a sua criação, em 1977, a Bibliographie d'histoire de l'éducation française que, em breve, estará disponivel no site <http: // www.inrp.fr /she/ accueil.htm>. 
é mais pela leitura das notas de rodapé de um artigo, de um livro ou de uma tese, ou ainda em meio a uma discussão ou troca de e-mail com algum colega, que passamos a conhecer a existência de trabalhos ou publicações que podem nos interessar. ${ }^{11}$

É preciso ainda consultar os documentos, tarefa que se revela freqüentemente difícil, quando não impossível, mesmo em nosso próprio país, notadamente quando se trata de uma dissertação acadêmica ou de um artigo publicado em uma revista de divulgação restrita. Ocorre ainda, e não tão raramente quanto se possa pensar, a existência de trabalhos anunciados que, por diversas razões, não chegam a ser publicados.

\section{Uma pesquisa dinâmica, profícua e de caráter nacional}

A despeito dessas dificuldades, parece ser necessário e particularmente oportuno fazer um balanço e esboçar uma análise, ainda que provisória, da pesquisa mundial.

Uma das razões essenciais é a onipresença - real ou bastante desejável - de livros didáticos pelo mundo e, portanto, o peso considerável que o setor escolar assume na economia editorial nesses dois últimos séculos. É impossivel para o historiador do livro tratar da atividade editorial da maior parte dos países sem levar isso em conta: em um país como o Brasil, por exemplo, os livros didáticos correspondiam, no início do século $X X$, a dois terços dos livros publicados e representavam, ainda em 1996, aproximadamente a $61 \%$ da produção nacional. ${ }^{12}$ Por ocasião do Primeiro Colóquio Mundial sobre a história da edição contemporânea que ocorreu em Sherbrooke, em maio de 2000, aproximadamente metade dos debatedores abordou a questão específica da edição didática, seja consagrando a ela parte ou toda sua comunicação, seja para se justificar por não tê-la considerado em seu campo de pesquisa. ${ }^{13}$

A segunda razão é seguramente o interesse que os historiadores têm demonstrado atualmente por essa área. Depois de ter sido negligenciada por longo tempo, as pesquisas históricas referentes aos livros didáticos e, posteriormente, às edições escolares, tiveram desde os anos 1960 e, sobretudo, nos últimos vinte anos, um considerável impulso. Ao fazer um balanço, em 1994, da história das edições na França, nos séculos XIX e XX, o historiador Jean-Yves Mollier constatou que a "primeira característica dessa disciplina em plena efervescência é [era] essencialmente a sua juventude", e ele assinalou que "a edição didática certamente é o setor mais dinâmico de hoje". ${ }^{14}$ Se alguns países já possuíam uma tradição mais ou menos consolidada na área da pesquisa histórica anterior aos anos 1980 (os Estados Unidos, já há um século, ${ }^{15}$ a Alemanha e o Japão, a partir do fim da Segunda Guerra Mundial, ${ }^{16}$ e, em menor escala, os países nórdicos, a GrãBretanha, a França e alguns países da Europa central), ${ }^{17}$ esse movimento atinge - por razões bastante diversas - um número cada vez maior de países: os países balcânicos (notadamente a Grécia e, mais recentemente, a Bulgária e a

11. É interessante notar que 0 site da Biblioteca da Universidade de Pittsburg oferece uma seleção da produção historiográfica dos Estados Unidos: <http: // www.digital.library.ptt.edu / nietz / webbibn.htm\#journal>

12. Decio Gatti Junior, "Dos antigos manuais escolares aos modernos livros didáticos de história no Brasil. Dos anos sessenta aos dias atuais", Icône, Vl/1 (2000), p. 97-116.

13. Alain Choppin, "Le manuel scolaire", in: Jacques Michon \& JeanYves Mollier (Dir.). Les mutations du livre et de l'édition dans le monde du XVIIle siècle à l'an 2000 (Paris-Sherbrooke, 2001), p. 474-483.

14. Jean-Yves Mollier, "L'Histoire du livre et de l'édition dans l'espace français", Bulletin de la Société d'histoire moderne et contemporaine, IIIIV (1994), p. 35-49.

15. Há muito tempo os americanos consideram os livros didáticos (e notadamente os readers) como agentes essenciais na formação da nação americana: Paul Leicester Ford, The New England primer, a history of its origin and development (New York, 1897); Clifton Johnson, Old-Time Schools and Schools Books (New York, 1904); Yates Snowden, South Carolina School Books, 1795-1865 (Columbia, 1910); etc.

16. A criação, na Alemanha, do Georg-Eckert-Institut für Internationale Schulbuchforschung, em Brunswick, em 1949, se inscreve na preocupação desse país em estabelecer relações de paz durável com seus antigos vizinhos e inimigos; contribuiu para fazer da análise ideológica dos conteúdos uma característica da pesquisa histórica na Alemanha desde a Segunda Guerra Mundial. No Japão, país no qual a questão dos livros didáticos suscita ainda hoje numerosas e acirradas polêmicas, a análise de conteúdo dos antigos manuais escolares - e do sistema de regras ao qual eles se submeteram respondeu e ainda responde - principalmente à preocupação em compreender a escalada do imperialismo japonês que conduziu à derrota de 1945.

17. Especialmente a Polônia, a ex-Tchecoslováquia e a Hungria, estes dois últimos países tendo catalogado suas coleções nacionais nos anos 1970 e 1980 
Romênia), a Itália, a Coréia e, sobretudo, as regiões de língua hispânica (particularmente a Argentina, o Chile, a Colômbia, a Espanha e o México) e de língua portuguesa (Portugal e, sobretudo, o Brasil).

Esse dinamismo da pesquisa resulta da convergência de uma série de fatores conjunturais que limitaremos a enumerar os principais: o crescente interesse manifestado pelos que se interessam pela história ou por historiadores profissionais em relação às questões da educação, área cuja demanda social se torna cada vez maior; o interesse de inúmeras populações em criar ou recuperar uma identidade cultural, devido a acontecimentos recentes como a descolonização, o desmantelamento do bloco comunista ou, ainda, ao recrudescimento de aspirações regionalistas e ao desenvolvimento de reivindicações provenientes de grupos minoritários; os avanços ocorridos na história do livro desde o início dos anos 1980, com a publicação ou produção de grandes obras de síntese sobre a história da edição contemporânea na França, Inglaterra, Espanha, Austrália, Canadá, na Suiça francofônica e em vários outros países; o considerável progresso nas técnicas de armazenamento, tratamento e difusão de informações, técnicas que se mostram as únicas capazes de trazer soluções adequadas à gestão e à valorização de um volume de documentos tão considerável quanto o das produções escolares; a constituição de equipes ou centros de pesquisa e de redes científicas internacionais que se dedicam às questões específicas do livro e das edições didáticas; ${ }^{18}$ as incertezas em relação ao futuro do livro impresso e, particularmente, em relação ao papel que os livros didáticos (textbooks) desempenharão diante das novas tecnologias educativas (teaching media).

Mas essa atividade científica tão abundante deve-se também a causas estruturais: a complexidade do objeto "livro didático", a multiplicidade de suas funções, a coexistência de outros suportes educativos e a diversidade de agentes que ele envolve.

Se hoje consideramos o livro didático como um objeto banal, um objeto tão familiar que parece inútil tentar defini-lo, o historiador que se interessa pela evolução dos livros escolares - ou das edições escolares - depara, logo de início, com um problema de definição. A natureza da literatura escolar é complexa porque ela se situa no cruzamento de três gêneros que participam, cada um em seu próprio meio, do processo educativo: de início, a literatura religiosa de onde se origina a literatura escolar, da qual são exemplos, no Ocidente cristão, os livros escolares laicos "por pergunta e resposta”, que retomam o método e a estrutura familiar aos catecismos; em seguida, a literatura didática, técnica ou profissional que se apossou progressivamente da instituição escolar, em épocas variadas - entre os anos 1760 e 1830, na Europa -, de acordo com o lugar e o tipo de ensino; enfim, a literatura "de lazer", tanto a de caráter moral quanto a de recreação ou de vulgarização, que inicialmente se manteve separada do universo escolar, mas à qual os livros didáticos mais recentes e em vários países incorporaram seu dinamismo e características essenciais. Essas categorias, sem se excluírem, freqüentemente se interpenetram como adverte lan Michel, para quem "é sempre difícil, ou talvez seja impossível, estabelecer uma distinção entre trabalhos escritos com um propósito didático específico e os escritos com objetivos de recreação". 19 Essas questões fronteiriças suscitaram uma literatura abundante, que apresenta diferentes respostas, segundo o lugar, a época e, até mesmo, a sensibilidade dos pesquisadores ou do ambiente político, religioso ou cultural em que trabalham.

É de se destacar ainda que os livros escolares assumem, conjuntamente ou não, múltiplas funções: o estudo histórico mostra

18. 0 Textbook Colloquium (<http: // www.open.ac.uk / OU / Academic / Arts / TEXTCOLI>), fundado em 1988 na Grã-Bretanha, que publicou a revista Paradigm; o International Textbook Research Network, fundado em 1991 e coordenado pelo Georg-Eckert-Institut de Brunswick, na Alemanha, e a Unesco (<http: // www.gei.de / newsletter / archive / nlpubso.htm>) que publica uma Newsletter anual; a International Association for Research on Textbooks and Educational Medias (IARTEM), fundada em 1995 na França, que organizou seis colóquios internacionais (<http: // www.iartem.no >).

19. Ian Michel, "The Historical Study of English as a Subject; a Preliminary Inquiry into some Questions of Method", History of Education, VIII/ 3 (1979), p. 202. Do original em inglês. 
que os livros didáticos exercem quatro funções essenciais, que podem variar consideravelmente segundo o ambiente sociocultural, a época, as disciplinas, os níveis de ensino, os métodos e as formas de utilização.

1. Função referencial, também chamada de curricular ou programática, desde que existam programas de ensino: o livro didático é então apenas a fiel tradução do programa ou, quando se exerce o livre jogo da concorrência, uma de suas possíveis interpretações. Mas, em todo o caso, ele constitui o suporte privilegiado dos conteúdos educativos, o depositário dos conhecimentos, técnicas ou habilidades que um grupo social acredita que seja necessário transmitir às novas gerações.

2. Função instrumental: o livro didático põe em prática métodos de aprendizagem, propõe exercícios ou atividades que, segundo o contexto, visam a facilitar a memorização dos conhecimentos, favorecer a aquisição de competências disciplinares ou transversais, a apropriação de habilidades, de métodos de análise ou de resolução de problemas, etc.

3. Função ideológica e cultural: é a função mais antiga. A partir do século XIX, com a constituição dos estados nacionais e com o desenvolvimento, nesse contexto, dos principais sistemas educativos, o livro didático se afirmou como um dos vetores essenciais da língua, da cultura e dos valores das classes dirigentes. Instrumento privilegiado de construção de identidade, geralmente ele é reconhecido, assim como a moeda e a bandeira, como um símbolo da soberania nacional e, nesse sentido, assume um importante papel político. Essa função, que tende a aculturar - e, em certos casos, a doutrinar - as jovens gerações, pode se exercer de maneira explícita, até mesmo sistemática e ostensiva, ou, ainda, de maneira dissimulada, sub-reptícia, implícita, mas não menos eficaz. ${ }^{20}$

4. Função documental: acredita-se que o livro didático pode fornecer, sem que sua leitura seja dirigida, um conjunto de documen- tos, textuais ou icônicos, cuja observação ou confrontação podem vir a desenvolver o espírito crítico do aluno. Essa função surgiu muito recentemente na literatura escolar e não é universal: só é encontrada - afirmação que pode ser feita com muitas reservas - em ambientes pedagógicos que privilegiam a iniciativa pessoal da criança e visam a favorecer sua autonomia; supõe, também, um nível de formação elevado dos professores.

O livro didático não é, no entanto, o único instrumento que faz parte da educação da juventude: a coexistência (e utilização efetiva) no interior do universo escolar de instrumentos de ensino-aprendizagem que estabelecem com o livro relações de concorrência ou de complementaridade influi necessariamente em suas funções e usos. Estes outros materiais didáticos podem fazer parte do universo dos textos impressos (quadros ou mapas de parede, ${ }^{21}$ mapasmúndi, diários de férias, coleções de imagens, "livros de prêmio" - livros presenteados em cerimônias de final de ano aos alunos exemplares - enciclopédias escolares...) ou são produzidos em outros suportes (audiovisuais, softwares didáticos, CD-Rom, internet, etc.). Eles podem, até mesmo, ser funcionalmente indissociáveis, assim como as fitas cassete e os vídeos, nos métodos de aprendizagem de línguas. 0 livro didático, em tais situações, não tem mais existência independente, mas torna-se um elemento constitutivo de um conjunto multimídia.

Enfim, é preciso levar em conta a multiplicidade dos agentes envolvidos em cada uma das etapas que marca a vida de um livro escolar, desde sua concepção pelo autor até seu descarte pelo professor e, idealmente, sua con-

20. Karl Peter Frtzsche, "Prejudice and underlying assumptions", in: Staffan Selander (Ed.), Textbooks and Educational Media (Stockholm, 1997), p. 107-114.

21. Esses instrumentos atraem particularmente a atenção dos historiadores. Ver Reinhard Stach \& Walter Müller, Schulwandbilder als Spiegel des Zeitgeistes zwischen 1880 und 1980 (Opladen, 1988); Christian Ritzi \& Ulrich Wiegmann (Org.), Zwischem Kunst und Pädagogik: zur Geschichte des Schulwandbildes in der Schweiz und der Deutschland (Baltmannsweiler, 1998). Um importante trabalho de catalogação das coleções belgas (programa Picture This) está em desenvolvimento pelas universidades de Louvain e de Gand. 
servação para as futuras gerações. A concepção de um livro didático inscreve-se em um ambiente pedagógico específico e em um contexto regulador que, juntamente com o desenvolvimento dos sistemas nacionais ou regionais, é, na maioria das vezes, característico das produções escolares (edições estatais, procedimentos de aprovação prévia, liberdade de produção, etc.). Sua elaboração (documentação, escrita, paginação, etc.), realização material (composição, impressão, encadernação, etc.), comercialização e distribuição supõem formas de financiamento vultuosos, quer sejam públicas ou privadas, e o recurso a técnicas e equipes de trabalho cada vez mais especializadas, portanto, cada vez mais numerosas. Por fim, sua adoção nas classes, seu modo de consumo, sua recepção, seu descarte são capazes de mobilizar, nas sociedades democráticas sobretudo, numerosos parceiros (professores, pais, sindicatos, associações, técnicos, bibliotecários, etc.) e de produzir debates e polêmicas.

Assim, a pesquisa histórica sobre os livros e as edições didáticas aborda aspectos extremamente diversos. E é essa multiplicidade de abordagens possiveis que faz com que a produção científica consista essencialmente em artigos isolados, o que torna mais difícil abarcá-la em seu conjunto. Apesar disso podemos nos arriscar a distinguir duas grandes categorias de pesquisa:

- aquelas que, concebendo o livro didático apenas como um documento histórico igual a qualquer outro, analisam os conteúdos em uma busca de informações estranhas a ele mesmo (a representação de Frederico 11 da Prússia, ${ }^{22}$ ou a representação da ideologia colonial, ${ }^{23}$ por exemplo), ou as que só se interessam pelo conteúdo ensinado por meio do livro didático (história das categorias gramaticais, por exemplo); ${ }^{24}$

- aquelas que, negligenciando os conteúdos dos quais o livro didático é portador, o consideram como um objeto físico, ou seja, como um produto fabricado, comercializado, distribuído ou, ainda, como um utensílio concebi- do em função de certos usos, consumido - e avaliado - em um determinado contexto.

No primeiro caso, a história que o pesquisador escreve não é, na verdade, a dos livros didáticos: é a história de um tema, de uma noção, de um personagem, de uma disciplina, ou de como a literatura escolar foi apresentada por meio de uma mídia particular; além disso, é freqüente que os livros didáticos constituam apenas uma das fontes às quais o historiador recorre. Na segunda categoria, ao contrário, o historiador dirige sua atenção diretamente para os livros didáticos, recolocando-os no ambiente em que foram concebidos, produzidos, distribuídos, utilizados e "recebidos", independentemente, arriscaríamos a dizer, dos conteúdos dos quais eles são portadores. Essa distinção é seguramente esquemática, uma vez que uma pesquisa geralmente participa - ainda que em proporções variáveis - das duas categorias. Nós a manteremos, no entanto, em nome da clareza e comodidade de nossa exposição.

Uma primeira observação de ordem geral diz respeito ao caráter nacional da literatura escolar. No Ocidente cristão, o surgimento da literatura escolar, no sentido moderno do termo, coincide com o período em que se constituem e se organizam, em um clima de intensa rivalidade religiosa, instituições encarregadas de assegurar a formação da juventude. Mas os objetivos, os conteúdos e os métodos de ensino serão revestidos então de uma dimensão "supranacional": são os mesmos produtos editoriais que, importados ou, mais tarde, produzidos no próprio local, se encontram em diferentes regiões da Europa ou do mundo onde floresceram associações de edu-

22. Michael Marker, Die Darstellung Friedrich des Großen in deutschen Lesebüchern für den Geschichtsunterricht an Gymnasien seit der Weimaren Republik (Münster, 1998).

23. Manuela Semidei, "De l'Empire à la décolonisation à travers les manuels scolaires français", Revue française de sciences politiques, XVI/ 1 (1966), p. 56-86.

24. Miroslaw Skarzynski, Czesci mowy i ich kategorie w gramatykach polskich XIX i XX wieku 1817-1938 (Cracóvia, 1994); Nadia Minerva \& Carla Pellandra (org.), Insegnare il francese in Italia. Repertorio analítico di manuali pubblicati dal 1625 al 1860 (Bolonha, 1997); etc. 
cadores. Na mesma época, se assiste, no Japão, a um fenômeno inverso. Na antiga Edo (16031867), a educação das jovens gerações ficava a cargo das comunidades locais, e milhares de livros destinados ao ensino elementar, os ôraimono, eram redigidos por todo o território japonês. ${ }^{25}$ Mas, no século XIX, quando os Estados nacionais, recentemente constituídos, reivindicam um papel de destaque na formação das novas gerações e aos poucos passam a substituir as famílias, total ou parcialmente, as autoridades religiosas, o livro escolar torna-se um símbolo da soberania nacional. As antigas colônias, notadamente na América Latina, ou os países que, como o Japão da era Meiji ou a China do início do século $X X^{26}$ que abrem-se à influência ocidental, vão adotar modelos educativos europeus ou neles se inspirar fortemente e colocar rapidamente em prática regulamentações específicas para controlar a elaboração, a produção, a distribuição e o uso das obras de cunho didático.

É fácil perceber, no entanto, ao percorrer bibliografias especializadas que a maioria, e em certos países "recentes" quase a totalidade, da produção científica relativa à história do livro e das edições didáticas recai sobre os dois últimos séculos de nossa história, período no qual são forjadas as identidades nacionais, quando se constituem as nações modernas. Sendo assim, a pesquisa se desenvolveu também em um contexto nacional, chegando, muitas vezes, a participar do processo de construção das identidades nacionais ou do processo de sua preservação. ${ }^{27}$

\section{Análise de conteúdos}

Não é casual, portanto, que os estudos mais antigos e mais numerosos digam respeito aos manuais escolares nacionais e se ocupem em analisar seu conteúdo. 0 controle da produção nacional contemporânea, de início, foi um ato administrativo pautado pela preocupação em subordinar os manuais ao discurso oficial, ou ainda com o de algum governo de ocupação, em um contexto de censura que tinha como objetivo eliminar ou evitar qualquer desvalorização ou qualquer interpretação nociva aos seus interesses. Tais controles também ficaram a cargo, desde o final do último século, de instituições independentes que se propuseram a extirpar dos livros didáticos, de diversos países, os estereótipos ou as asserções passíveis de suscitar ou de alimentar o desentendimento entre os povos ou de colocar a paz em perigo. ${ }^{28}$ Mas, também nesse caso, trata-se de confrontações de visões nacionais.

0 mesmo aconteceu, conseqüentemente, no domínio da pesquisa acadêmica. A análise científica dos conteúdos é marcada por duas grandes tendências: a primeira, por muito tempo privilegiada pelos pesquisadores e que continua ainda na atualidade, refere-se à crítica ideológica e cultural dos livros didáticos; a segunda, mais recente, mas que tem sido cada vez mais considerada desde o final dos anos 1970, analisa o conteúdo dos livros didáticos segundo uma perspectiva epistemológica ou propriamente didática.

Após a análise do livro didático contemporâneo segundo essas duas abordagens, aliás indissociáveis, mas infelizmente quase sempre tratadas de maneira independente e excludente, tomaram-se como objeto de estudo os manuais

25. Matsutarô Ishikawa, Ôraimono no seiritsu to tenkai [ Surgimento e desenvolvimento dos ôraimono] (Tókio, 1988).

26. Michela Bussotti, "L'Édition traditionnelle chinoise et l'introduction des techniques occidentals XVIIe-XIXe siécles", in: Jacques Michon \& JeanYves Mollier, Les mutations du livres, p. 374-391.

27. Dessa forma, a numerosa produção científica dos Estados Unidos participa da celebração dos princípios e valores que fundam a democracia americana. Sendo assim, podemos observar, de um lado, a numerosa literatura científica dedicada, há mais de um século, aos manuais de Noah Webster ou ao McGuffey Eclectic Readers e, de outro, o trabalho bastante tardio e isolado que Charles Monaghan acaba de dedicar a Lindley Murray e a seu English Reader. Esse livro, publicado em 1799, teve, no entanto, 159 edições, entre 1815 e 1836, e vendeu cerca de 11 milhões de exemplares no território americano, entre 1800 e 1849. Mas, o longo silêncio da historiografia americana deve-se, sem dúvida, ao fato de que esse quaker, originário da Pensilvânia, teve de se exilar na Inglaterra porque seu pai continuou a fazer comércio com a Inglaterra durante a Guerra da Independência. Charles H. Carpenter, que em parte Ihe faz justiça em sua History of American schoolbooks, observa, além disso, que a maior parte dos historiadores americanos the atribuem erroneamente nacionalidade inglesa. CF. Charles Morgan, The Murrays os Murray Hill (Nova York, 1998).

28. Essas questões suscitaram abundante literatura, notadamente na Alemanha pós-Segunda Guerra Mundial. 
escolares mais antigos. Trata-se então, ou de colocar em evidência as principais características de um livro ou de uma coleção de livros, ou, segundo uma perspectiva diacrônica, de delimitar sua evolução por meio da análise de várias gerações de manuais ou de edições sucessivas - e freqüentemente bastante numerosas - de um mesmo livro. As pesquisas que se referem ao conteúdo ideológico e cultural dos antigos manuais escolares ou da imagem que eles apresentam da sociedade têm se mantido como o essencial da produção científica nos últimos vinte anos. Se tomarmos o exemplo da França, esse tipo de análise de conteúdo representou quase a metade das publicações científicas entre 1960 e $1980 .{ }^{29}$ Não temos estudos equivalentes para que possamos fornecer estatísticas para os demais países, mas a convivência com bibliografias mostra que essa categoria de análises representa ainda a maior proporção de pesquisas efetuadas ou em curso, notadamente nos países que ainda não têm tradição nessa área.

Considera-se que as análises desenvolvidas segundo uma perspectiva ideológica ou sociológica quase sempre trazem respostas ou ao menos esclarecimentos às questões que a sociedade contemporânea se coloca. Se os temas abordados são múltiplos, eles revelam, em cada país, preocupações comuns e recorrentes, ou então questões relacionadas a determinados acontecimentos localizados em determinado tempo e espaço.

A análise desses temas mostra ainda que determinadas questões são freqüentemente retomadas em cada país: as que se referem à formação da identidade nacional, e que são as mais comuns, notadamente em países que conquistaram autonomia ou que a recuperaram recentemente, ou ainda naqueles nos quais o poder político preocupa-se em consolidar ou alimentar - por razões diversas - o sentimento de nacionalidade. Dentre as questões também muito freqüentes destacam-se as que se relacionam com a inserção social, desde a aprendizagem de regras de boas maneiras até a educação para a cidadania, ou ainda as referentes à aprendizagem da leitura.
Mas essa análise também mostrou que são abordados temas relacionados à atualidade ou a um contexto nacional particular: assim a questão das minorias negras nos Estados Unidos tem sido objeto de várias publicações desde $1941 ;^{30}$ o debate sobre a descolonização suscitou uma abundante literatura na França, a partir de meados dos anos 1960. Os períodos do nacional-socialismo, do imperialismo japonês e, mais recentemente, a fase franquista chamaram particularmente a atenção dos historiadores alemães, japoneses e espanhóis que têm estudado a produção da época ou analisado a imagem apresentada pelos livros didáticos atuais sobre tais períodos. Exemplos desse tipo poderiam ser multiplicados.

Mas observemos também que podemos fazer uma leitura negativa dessas temáticas, pois, se alguns temas ou períodos são tratados à exaustão em determinados lugares, outros podem ser totalmente ignorados. Esta situação, é preciso lembrar, talvez ocorra pelo fato de as autoridades não garantirem àqueles que estão sob sua jurisdição o direito de se expressar livremente, o que explica a ausência de qualquer pesquisa em (mas não necessariamente sobre) um grande número de países, notadamente aqueles que, de jure ou de fato, têm edições produzidas pelo Estado. Mas isso também pode se dever ao fato de que o pesquisador não chegou a abandonar os preconceitos constitutivos de sua própria identidade cultural. Essas escolhas e esses silêncios remetem à delicada questão do papel do pesquisador e de sua impossível objetividade. "Uma vez que é impossivel estabelecer critérios de avaliação inequívocos, sem a ajuda de procedimentos científicos, essas mesmas análises estão sujeitas a participar de uma ideologia, e podemos considerar que certas pesquisas existentes nada mais fazem que tentar substituir ideologias (reais ou presumi-

29. Choppin, "L'Histoire des manuels scolaires: um bilan bibliométrique", op. cit. p. 174-175.

30. Marie Elizabeth Carpenter Ruffin, The treatment of the Negro in American History school textbooks; a comparison of changing textbook content, 1826 to 1939 (Mesasha, 1941). 
das) que elas identificaram por meio de outras ideologias”, observou Wolfgang Marienfeld. ${ }^{31}$

Conclui-se que a imagem da sociedade apresentada pelos livros didáticos corresponde a uma reconstrução que obedece a motivações diversas, segundo época e local, e possui como característica comum apresentar a sociedade mais do modo como aqueles que, em seu sentido amplo, conceberam o livro didático gostariam de que ela fosse, do que como ela realmente é. Os autores de livros didáticos não são simples espectadores de seu tempo: eles reivindicam um outro status, o de agente. 0 livro didático não é um simples espelho: ele modifica a realidade para educar as novas gerações, fornecendo uma imagem deformada, esquematizada, modelada, freqüentemente de forma favorável: as ações contrárias à moral são quase sempre punidas exemplarmente; os conflitos sociais, os atos delituosos ou a violência cotidiana são sistematicamente silenciados. E os historiadores se interessam justamente pela análise dessa ruptura entre a ficção e o real, ou seja, pelas intenções dos autores. Estudar, por exemplo, as imagens que os manuais escolares alemães, publicados entre 1933 e 1945, apresentam da Rússia, nos dá maiores indicações sobre as concepções políticas do regime nacional-socialista e sobre sua ideologia do que sobre a organização da URSS dessa mesma época. ${ }^{32}$

Não é suficiente, no entanto, deter-se nas questões que se referem aos autores e ao que eles escrevem; é necessário também prestar atenção àquilo que eles silenciam, pois se o livro didático é um espelho, pode ser também uma tela. Essa observação não vale apenas para os livros didáticos de história ou de literatura, que imediatamente nos vêm à mente; a análise de livros didáticos de ciências mostra que estes também apresentam uma visão consensual e normalizada do estado da ciência de sua época; toda controvérsia é deliberadamente eliminada da literatura escolar. ${ }^{33}$

Compreende-se que, na hipótese do pesquisador, de forma explícita ou implícita, se interessar essencialmente pela história das mentalida- des e pelos processos de aculturação, sejam privilegiados os estudos de livros destinados ao ensino popular (em outros termos, às escolas primárias) ao menos sobre os dois últimos séculos.

Essa opção ocorre porque, levando-se em conta a população efetivamente escolarizada ou escolarizável, são esses livros que tiveram maior difusão e que, portanto, são considerados como os mais influentes e mais importantes na formação das mentalidades, ainda mais porque são destinados aos mais jovens. Essa mesma lógica leva os pesquisadores a tratarem apenas dos livros didáticos que parecem ter tido grandes tiragens, e os leva a concentrarem-se em um só título, ou seguidores de um modelo padronizado. Explica-se, desta forma, o caráter repetitivo de várias produções científicas, nas quais o recurso a um fundo documental potencialmente considerável mostra-se, paradoxalmente, extremamente limitado: os pesquisadores analisam sempre os mesmos manuais escolares.

Podemos apontar ainda uma outra razão: acredita-se que os conteúdos, em última instância limitados, e a apresentação esquemática contida nos livros destinados aos mais jovens ofereça - ainda que isso não passe de aparência enganosa - menos dificuldades para a análise que aos livros didáticos destinados aos níveis superiores. Talvez essa seja a principal razão do sucesso, mas também dos desvios, vividos e ainda por viver pela análise do conteúdo ideológico e cultural dos livros didáticos: desenvolve-se esse tipo de análise, em um número bastante grande de universidades, apenas como um simples exercício acadêmico. Um acontecimento, um personagem, um tema ou conceito ou um corpus, limitado por uma disciplina, um nível de ensino, um determinado tempo histórico... 0 livro didático tornou-se, assim, e isso não parece ser uma particularidade

31. Wolfgang Marienfeld, "Schulbuchanalyse und Schulbuchrevision: Zur Methodenproblematik", Internationales Jahrbuch für Geschichts-und Geographieunterricht, XVI (1976), p. 49.

32. Marina Hahn, Das Rußlandbild im deutschen Schulbuch 1933-1945 (Frankfurt am Main, 1993).

33. John Hedley Brooke, "Textbooks and the history of science", Paradigm, XXV (1998), p. 35-37. 
francesa, um tema relativamente simples para o pesquisador iniciante.

0 predomínio de pesquisas sobre os livros didáticos do ensino primário e os objetivos determinados pela análise de conteúdo necessariamente influem na distribuição das disciplinas estudadas. Os trabalhos centrados na análise de conteúdo dos antigos manuais escolares por muito tempo consideraram apenas os livros de aprendizagem ou reforço de leitura (abecedários, silabários, cartilhas, livros de leitura, antologias), os livros de história e de forma complementar os de geografia - e, quando há livros específicos, de boas maneiras, de moral, de educação cívica e até mesmo de canto. Já os manuais escolares de matérias científicas por muito tempo chamaram a atenção por aquilo que não diz respeito especificamente à sua disciplina: assim, a análise de conteúdo dos livros de aritmética focalizaram-se na enunciação dos problemas que, por exporem situações concretas, remetem-se a uma certa imagem da sociedade ou difundem, propositadamente, uma mensagem ideológica ou moralizante. $^{34}$

Nos anos 1970 opera-se, progressivamente, uma mudança de perspectiva na análise de conteúdo dos antigos manuais escolares. As dificuldades vividas então pelos principais sistemas educativos ocidentais levam os pesquisadores a se interrogarem sobre as finalidades do ensino, sobre seus conteúdos e métodos e, entre outras coisas, a colocarem aos antigos manuais escolares questões de natureza epistemológica e didática propriamente dita: qual(s) discurso os ma-nuais sustentam sobre determinada disciplina e sobre seu ensino? Qual(s) concepção(s) de história, qual(s) teoria(s) científica(s) ou qual(s) doutrina(s) lingüística(s) representam ou privilegiam? Qual o papel que atribuem à disciplina? Que escolhas são efetuadas entre os conhecimentos? Quais são os conhecimentos fundamentais? Como eles são expostos, organizados? Quais métodos de aprendizagem (indutivo, expositivo, dedutivo, etc.) são apresentados nos manuais?

Essa renovação na análise dos conteúdos, que não está dissociada dos avanços vivi- dos então pela lingüística e pela história das ciências, se traduz por uma extensão do domínio de investigação no conjunto das disciplinas e dos níveis de ensino. Com efeito, se a análise do conteúdo ideológico e cultural transcende as disciplinas e naturalmente a preferência recai sobre os livros didáticos que apresentam um conteúdo mais genérico, o mesmo não ocorre com a análise epistemológica e didática: ela se ancora em uma disciplina de referência que possui suas próprias finalidades, seus conteúdos de ensino e seus métodos de aprendizagem específicos. É certo, entretanto, que os estudos que se referem aos livros didáticos de história ou de leitura sempre correspondem à maioria da produção científica: basta consultar as bibliografias ou os programas de congressos e colóquios. Mas as disciplinas de maior destaque no ensino secundário e que até então tinham sido relativamente pouco analisadas, como a geografia, as matemáticas ou a gramática ou, muitas vezes, até mesmo negligenciada, como a física, a química a zoologia ou as línguas, antigas e, sobretudo, modernas, têm sido objeto de trabalhos cada vez mais numerosos. ${ }^{35}$

34. Guy Vincent, "L'arithmétique morale", Cahiers d'histoire, XXI (1976), p. 199-209; André Harlé, L'arithmétique des manuels de l'enseignement élémentaire français du début du XXe siècle (Paris, 1984).

35. Fornecer uma lista, ainda que sumária, das publicações nas diversas disciplinas extrapola os limites desse artigo, nesse sentido nos reservamos 0 direito de fazê-lo em um outro contexto. Portanto, sem pretender esgotar 0 assunto, e sem pretender fazer exclusões deliberadas, citamos aqui alguns dos trabalhos mais representativos da importância que a análise dos livros didáticos ganhou na história das disciplinas até então pouco estudadas. Para a geografia, as de Horacio Capel Sáez, na Espanha, as de Wiliam E. Marsden e de Norman J. Graves, na Grã -Bretanha ou as de Clara Tremolada, na Itália; para as matemáticas, as de Wagner Rodrigues Valente, no Brasil, de John Fauvel, na Grã-Bretanha; para a gramática e para as línguas antigas e nacionais, os de André Chervel, na França, de lan Michael ou de Chris Stray, na Grã-Bretanha, de Helmut Nierderländer ou de Britta Stanze, na Alemanha, de Mario Mormile, de Maria Catricalà, ou de Carla Pellandra e Nadia Minerva, na Itália, de Simão Cardoso ou de Rui Vieira de Castro, em Portugal; para a literatura nacional, as de lan Michael ou de Ellen Alwall, na Grã-Bretanha, de Georg Rentner, na Alemanha; para o ensino de línguas estrangeiras, as de Umberto Gorini (alemão na Itália), de Maja Häusler (alemão na Croácia), de Paul Gerbod (francês na Grã-Bretanha), de Peter Loonen (inglês nos Países Baixos), de Ingar Bratt (inglês na Suécia), de Elizabet Hammar (francês na Suécia), da Katin Wippich-Rohácková (espanhol na Alemanha); para as ciências naturais, as de Colin McGeorge, na Nova Zelândia, ou a de Yves Cambefort, na França; para a física, as de Gunter Lind, na Alemanha e, para a química, as numerosas contribuições (em uma dezena de países) à obra coletiva de Anders Lundgren e Bernadette Bensaude; etc. 
As últimas transformações na análise de conteúdo dos livros didáticos referem-se ao próprio material sobre o qual se baseia seu estudo. Por razões que dizem respeito à formação de pesquisadores e à carência de instrumentos apropriados, as análises dos livros didáticos, independentemente de suas problemáticas, ficam tradicionalmente restritas - ao menos no Ocidente - à análise de texto. 0 privilégio quase exclusivo conferido à análise textual, mesmo considerando que desde o final do século passado a parte do livro destinada à iconografia não tenha deixado de crescer, se solidificou pelo desenvolvimento de métodos e de instrumentos de análises lingüísticas, destacando a análise lexicométrica. Foi no final dos anos 1980, com os avanços da semiótica, o impulso da história das mentalidades e o interesse pelas questões de vulgarização das ciências, que recorreu a muitos esquemas e gráficos, que o livro didático deixou de ser considerado como um texto subsidiariamente "enfeitado" de ilustrações, e para que a iconografia didática - e a articulação semântica que une o texto e a imagem - tenha sido levada em conta. ${ }^{36}$

Nos anos 1990, a função instrumental passou a ganhar uma atenção crescente dos educadores e, em menor escala, dos historiadores de livros didáticos. Estes receiam que uma análise das características "pedagógicas" dos livros didáticos predomine de tal forma que, no limite, esqueçam as características próprias do livro: "É difícil evitar que esse tipo de análise das características recaia em uma extensa discussão sobre os métodos de ensino que acabe por manter afastado o próprio livro". ${ }^{37}$ Sob esse ponto de vista, apenas os prefácios foram considerados dignos de interesse, na medida em que, nos limites de uma exposição sucinta, elaborada e refletida, tais prefácios permitem discernir os projetos conscientes - confessados, ou confessáveis - dos autores e medir a clivagem entre os princípios alegados e a aplicação que deles é feita no livro. No entanto, outros elementos, até mais reveladores das intenções ideológicas ou pedagógicas dos auto- res, como as notas de rodapé, os resumos, a formulação dos títulos e subtítulos dos capítulos, os sumários, o léxico, os índex ou, simplesmente, o próprio título dos livros mereceriam ser estudados com mais cuidado.

Também têm sido negligenciadas as características "formais" dos livros didáticos. A organização interna dos livros e sua divisão em partes, capítulos, parágrafos, as diferenciações tipográficas (fonte, corpo de texto, grifos, tipo de papel, bordas, cores, etc.) e suas variações, a distribuição e a disposição espacial dos diversos elementos textuais ou icônicos no interior de uma página (ou de uma página dupla) ou de um livro só foram objeto, segundo uma perspectiva histórica, de bem poucos estudos, apesar dessas configurações serem bastante específicas do livro didático. Com efeito, a tipografia e a paginação fazem parte do discurso didático de um livro usado em sala de aula tanto quanto o texto ou as ilustrações. ${ }^{38}$

\section{A elaboração de importantes instrumentos de pesquisa}

Ao lado dos "tradicionais" estudos que se dedicam a analisar os conteúdos de um livro didático considerado exemplar, a produção de um autor considerado influente ou um número limitado de obras, cuja constituição é geralmente aleatória e a representação, desse modo, sujeita a questionamento, surgiram, de uns 25 anos para cá, e em um número cada vez

36. Yves Gaulupeau, 'L'Histoire en images à l'école primaire. Un exemple: la Révolution dans les manuels élémentaires (1870-1970)", Histoire de l'education, XXX (1986), p. 29-52; Pierre Guibbert, "L'Image subordonnée aux mots: essai de caractérisation fonctionelle de l'illustration des manuels de français", Internationale Schulbuchforschung. Zeitschrift des GeorgEckert-Instituts, XVI/4 (1994), p. 447-464; Dora Santos-Bernard, The use of illustrations in school mathematics textbooks: presentation of information (Nottingham, 1997).

37. Ian Michael, "Textbooks as history: the work of the Colloquium", Paradigm, XXV (1998), p. 32. Do original em inglês.

38. Michael Twyman, "Textbook design: chronological tables and the use of typographic cueing", Paradigm, IV (1990), pp. 12-17. Os trabalhos mais significativos sobre a organização interna dos livros didáticos e sua paginação parecem terem sido realizados na Austrália. Cf. Theo Van Leeuwen, "The schoolbook as a Multimodal Text", Internationale Schulbuchforschung. Zeitschrift des Georg-Eckert-Instituts, XIV/1 (1992), p. 35-58. 
maior de países, uma série de novos campos de pesquisa. Essas iniciativas, isoladas ou em conjunto, apresentam três características essenciais: acumulação de dados e sistematização - até mesmo normalização - de abordagens e métodos; extensão de domínios de investigação e diversificação de problemáticas; consideração de perspectivas comparativas e transacionais.

Manifesta-se, no final dos anos 1970, uma preocupação em romper com a fragmentação e com o empirismo característicos, até então, das pesquisas que se referiam à história da literatura escolar. ${ }^{39}$ Ao analisar a produção anglosaxã, G. H. Harper chegou, em 1980, a uma dura constatação:

É de se lamentar a qualidade de um número de estudos surgidos nos anos 60 e esperamos que não surjam outros similares. 0 objetivo geral era fazer uma lista cronológica floreada de livros didáticos, algumas vezes omitindo as matérias que não são mais ensinadas nos dias atuais, com comentários anedóticos e triviais; algumas vezes nem mesmo havia uma bibliografia dos livros mencionados. Esses estudos, em geral, mal escritos, aparentemente sem revisão de professores e baseados em hipóteses ingênuas do papel seminal dos livros didáticos na formação de líderes e da civilização do país envolvido. ${ }^{40}$

0 autor defende, então, a redação de um Guide pour la recherche historique sur les manuels scolaires, uma iniciativa que desempenhará um papel essencial no desenvolvimento do Textbook Colloquium, menos de dez anos depois. Nesse mesmo ano, foi publicado, na revista Histoire de l'education, o artigo no qual, depois de traçar um rápido resumo da pesquisa histórica francesa sobre o livro escolar e discutir questões de método, propusemos uma série de pistas e de possibilidades de campos de pesquisa, que posteriormente foram apresentados no plano de pesquisa Emmanuelle. ${ }^{41}$ Essas idéias, que se inscreveram na perspectiva de tidas nos anos subse- qüentes por numerosos pesquisadores, notadamente na Espanha, Grécia, Portugal, Colômbia, Itália, Brasil e, de modo mais geral, na América Latina. $^{42}$

A preocupação demonstrada em recolocar a literatura escolar em seu contexto e, portanto, de considerar de forma sistemática o conjunto de parâmetros que influenciam sua evolução, manifesta-se notadamente na constituição de grandes instrumentos de pesquisa, catalogação, coleta e compilação de fontes.

0 primeiro campo de envergadura trata da regulamentação aplicada às produções escolares. Uma vez que são destinadas a espíritos jovens, ainda maleáveis e pouco críticos, e podem ser reproduzidos e distribuidos em grande número sobre todo um território, os livros didáticos constituíram-se e continuam a se constituir como poderosos instrumentos de unificação, até mesmo de uniformização nacional, lingüística, cultural e ideológica. Isso porque, em grande parte dos países, eles são objeto de uma regulamentação que difere sensivelmente daquela a que são submetidas as demais produções impressas; regulamentação que é geralmente mais estrita, quer ela se exerça no início (elaboração, concepção, produção, procedimentos prévios de aprovação) ou ao

39. Coeckelberghs, "Das Schulbuch"; Colin Mc George, "The use of Schoolbooks as a source for the History of Education, 1878-1914", New Zealand Journal of Educational Studies, XIV/2 (1979), p. 138-151.

40. G. H. Harper, "Textbooks: an under-used Source", History of Education Society Bulletin, XXV (1980) , p. 31. Do original em inglês. 41. Choppin, "Les manuels scolaires: une approche globale".

42. Buenaventura Delgado, "Los libros de texto como fuente para la historia de la Educatión", Historia de la Educación, II (1983), p. 353-358; Christina Koulouri, "Scholika encheiridia kai historike ereuna", Mnemon, XI (1987), p. 219-224; Justino Pereira de Magalhães, "Um apontamento para a história do manual escolar entre a produção e a representação", in: Rui Vieira de Castro, Angelina Rodrigues, José Luis Silva \& Maria Lourdes Dionísio de Sousa (Org.), Manuais Escolares: Estatuto, Funções, História. Actas do I Encontro internacional sobre manuais escolares (Braga, 1999), p. 279- 302; Maria Victória Alzate Piedrahita, Miguel Angel Gómez Mendoza \& Fernando Romero Loaiza, Textos escolares y representactiones sociales de la família. I. Definiciones, Dimensiones y Campos de investigación (Santafé de Bogotá, 1999), p. 28-38; Paolo Bianchini, "Una fonte per la storia dell'istruzione e dell'editoria in Italia: il libro scolastico", Contemporánea, III/1 (2000), p. 175-182; Antonio Augusto Gomes Batista, "Um objeto variável e instável: textos, impressos e livros didáticos", in: Márcia Abreu (Org.), Leitura, história e história da leitura (Campinas, 2000), p. 529-575; Gabriela Ossenbach Sauter \& Miguel Somoza, Los manuales escolares como fuente para la historia de la educatión em América Latina (Madri, 2001). 
final do processo (modos de financiamento, de difusão, procedimentos de escolha, formas de utilização). 0 estudo sistemático do contexto legislativo e regulador, que condiciona não somente a existência e a estrutura, mas também a produção do livro didático, é condição preliminar indispensável a qualquer estudo sobre a edição escolar. ${ }^{43}$ Escrever a história dos livros escolares - ou simplesmente analisar o conteúdo de uma obra - sem levar em conta as regras que o poder político, ou religioso, impõe aos diversos agentes do sistema educativo, quer seja no domínio político, econômico, lingüístico, editorial, pedagógico ou financeiro, não faz qualquer sentido.

Observa-se também, de uns vinte anos para cá, em um número crescente de países, o desenvolvimento de trabalhos que se esforçam em coletar documentos de arquivos muito dispersos, em reconstituir, parcial ou totalmente, a história da política nacional para o livro didático. Alguns trabalhos nessa linha foram concluídos ou estão em fase de conclusão, na Alemanha, Espanha, França, Grécia, Japão, Ontário, Quebec e Suiça; outros estão em curso, ou em fase de projeto como no caso da Argentina, Colômbia, Hungria, Itália, México e em Portugal, lista que certamente não é exaustiva. ${ }^{44}$

Uma mesma preocupação com uma coleta sistemática, de acumulação e difusão de informações, anima a todos aqueles que, em várias partes do mundo, decidiram, por razões de preservação patrimonial ou meramente científicas, recensear a produção escolar de seu país. Não há necessidade de lembrar, mais uma vez, as múltiplas razões que levaram historiadores, colecionadores, bibliógrafos e bibliotecários a negligenciar por tanto tempo os livros didáticos, nem aquelas que, desde os anos 1970, militam em favor de sua reabilitação. Se deixarmos de lado os catálogos de editoras - que dificilmente são conservados, ou o são apenas parcialmente - as raras listas de livros didáticos que foram elaboradas antes dessa data se inscreveram essencialmente em duas perspectivas:
- a maior parte faz o recenseamento da produção contemporânea; provém de instâncias governamentais e responde à necessidade, nos países que ainda recorrem a procedimentos de aprovação na esfera institucional, de fornecer aos educadores a lista de obras que eles podem utilizar; ${ }^{45}$

- os demais, bem menos numerosos, correspondem a iniciativas isoladas; foram elaboradas no contexto de trabalhos acadêmicos, dos quais constituem parte das fontes, ou correspondem à preocupação de um ou outro bibliotecário em recuperar fundos gerais e negligenciados da biblioteca.

Se, a partir dos anos 1980, as iniciativas em fazer o recenseamento da produção escolar se multiplicaram, também mudaram de dimensão: tais operações não mais se limitaram a inventariar uma lista específica de livros ou elaborar uma bibliografia seletiva ou indicativa; visam, de agora em diante, a serem exaustivas. Também mudaram de objetivo: não são mais realizadas somente por bibliotecários preocupados em preservar um patrimônio, ou, no que se refere às coleções mais recentes, por docu-

43. Alain Choppin, "Las políticas de libros escolares en el mundo: perspectiva comparativa e histórica", in: Javier Pérez Siller \& Verena Radkau García (coord..), Identidad en el imaginario nacional: reescritura e enseñanza de la historia (Puebla- Braunschweig, 1998), p. 169-184.

44. Michael Sauer, "Zwischen Negativkontrolle und staatlichen Monopol: zur Geschichte von Schulbuchuhzulassung und -einführung", Geschichte in Wissenschaft und Unterricht, IL (1998), p. 144-156; José Luis Villalaín Benito, Manuales escolares en España. Tomo I. Legislación (1812-1939). Estudio preliminar de Manuel de Puelles Benítez (Madri, 1997); Alain Choppin \& Martine Clinkspoor, Les manuels scolaires en France de la Révolution à nos jours. 4. Texts officiels (1791-1992) (Paris, 1993); Christina Koulouri \& Ekaterini Venturas, "Les manuels scolaires dans I'État grec, 1834-1937", in: Alain Choppin (Dir.) Manuels scolaires: Etats et sociétés, XIXe-XXe siècles, op. cit., p. 9-26; Masafumi Kajiyama, Kindai nihon kyôkashoshi kenkyû - meijiki kentei seido no seiritsu to okay [Pesquisa sobre a história dos livros didáticos do Japão contemporâneo — 0 "sistema dos manuais escolares autorizados" da época Meiji; de sua instauração ao seu fim] (Kioto, 1988); Paul Aubin, L'État quebécois et le manuel scolaire au XIXe siècle (Sherbrooke, 1995); o campo aberto por Viola Elizabeth Parvin, Authorization of textbooks for the schools of Ontario, 18461950 (Toronto, 1965) foi retomado pela universidade de Ottawa; Patrick De Leonardis \& François Vallotton, "Legislation, politique et édition au XIXe siècle: le cas des manuels d'histoire dans le canton de Vaud", Revue Historique Vaudoise (1997), p. 19-56.

45. É, por exemplo, o caso do Japão ou de 21 dos estados que compõem os Estados Unidos. 
mentalistas que têm por objetivo colocar os livros didáticos à disposição de educadores ou sociólogos; mas estão inseridos no procedimento de historiadores interessados em efetuar uma pesquisa científica. Os tratamentos bibliográfico e documental tradicionais foram substituídos por novas abordagens que implicam uma nova definição do objeto, novos métodos de análise e novas exigências no acesso aos documentos.

Três condições favoreceram a abertura de campos de pesquisa cujos itens se contam aos milhares, dezenas de milhares, ou até mais: em primeiro lugar, o recurso a técnicas informatizadas para a coleta, tratamento e difusão de informações; em seguida, a constituição de programas de pesquisa coletiva, inter-universitárias, nacionais ou internacionais e, enfim, a acumulação e formas de compartilhar experiências e habilidades em congressos internacionais ou, mais diretamente, pelas trocas de correspondência entre pesquisadores.

Nesse sentido, o programa Emmanuelle, desenvolvido no Departamento de História da Educação do INRP, desde 1980, ao fazer uso de técnicas informatizadas, constituiu-se como um verdadeiro pólo de referência para a comunidade científica internacional; sendo assim, a maior parte das iniciativas ulteriores tomou como ponto de partida o banco de dados desenvolvido nesse programa. ${ }^{46}$ Nesse contexto, vários projetos que têm a pretensão de contabilizar de forma exaustiva toda ou parte da literatura escolar de seu país foram desenvolvidos nesses últimos 25 anos, a maioria dos quais deu lugar a publicações, ainda que parciais: na Bélgica, sob a iniciativa das universidades de Gand e de Louvain (programa Picture this) ${ }^{47}$ em Quebec, pela Universidade Laval; ${ }^{48}$ em Ontário, pela Universidade de Ottawa (programa Mascofo); na Espanha, pela UNED, de Madri (programa Manes, que reúne a maior parte das universidades espanholas e abrange atualmente numerosas universidades da América Latina interessadas no recenseamento de suas respectivas produções nacionais); ${ }^{49}$ em Portugal, pela Universidade do Minho, de Braga (programa
Eme) $;^{50}$ no Brasil, em diversos centros de pesquisa, ${ }^{51}$ mas sobretudo no Centro de Memória da Educação da Faculdade de Educação da Universidade de São Paulo $;^{52}$ na Alemanha, a partir do Georg-Eckert-Institut de Brunswick; ${ }^{53}$ na Itália, sob a iniciativa da Universidade de Turim (programa Edisco) $;^{54}$ na Universidade de Luján, na Argentina (programa Histelea) ${ }^{55}$ ou ainda na República Democrática do Congo, a partir do programa Aequatoria, desenvolvido por Honoré Vinck; ${ }^{56}$ etc. Encontramos também várias outras atividades similares, freqüentemente desenvolvidas por bibliotecas detentoras de importantes coleções, como na Hungria (Budapeste), na ex-Tchecoslováquia (Bratislava), na Suécia (Estocolmo), na Grã-Bretanha (Bristol, Durham, Leeds, Londres [Institute of Education Library], Reading, etc.) nos Estados Unidos (Universidade de Illinois, em Urbana-Champaign, Universidade de Pittsburgh, Universidade de Colúmbia, Universidade de Harvard, etc.) etc. Tais iniciativas, desenvolvidas por pesquisadores ou instituições isoladas, ou inscritas em

46. <http: // www.inrp.fr / she / emmanuellle.htm>. 0 banco de dados Emmanuelle está acessível desde 2001

47. Karl Catteeuw, Marc Depaepe \& Frank Simon, "Forschungsprojekt 'Pädagogisches Gedächtins Flanderns'", Internationale Schulbuchforschung. Zeitschrift des Georg-Eckert-Instituts,XX/3 (1998), pp.313-325.

48. <http: // www.ulaval.ca/ress / mansco>. Bastante conhecido, esse site remete a outros sites similares.

49. <http: // www.uned.es / manesvirtual /portalmanes.html>

50. Rui Vieira de Castro, "O Projeto Eme", in: Rui Vieira de Castro, Angelina Rodríguez, José Luís Silva \& Maria Lourdes Dionísio Sousa (Org.), Manuais escolares, p. 547-550.

51. Por exemplo em Minas Gerais: foi feito, em 1996, um cadastramento das coleções de manuais reunidos pelo Centro de Referência do Professor de Belo Horizonte; está em andamento, no Centro de Alfabetização, Leitura e Escrita (Ceale), da Universidade Federal de Minas Gerais um projeto de cadastramento dos manuais de leitura publicados entre 1868 e 1950: <http: // www.fae.ufmg.br / gephe 6dute.htm>. Outros projetos estão em estudo no Rio Grande do Sul.

52. <http: // apache.fe.usp.br / laboratorios /cmemoria>

53. < http: // www.gei.de / geihome.htm>.

54. <http // www.far.unito.it / edisco >: Programa dirigido por Giorgio Chiosso e coordenado por Paolo Bianchini.

55. <http: // www.unlu.edu.ar / museo / Histelea.htm>. Ver Héctor Rubén Cucuzza, "Hacia una historia social de la lectura y escritura: el proyecto HISTELEA". Ponencia presentada en Segundo Seminario International textos escolares en Ibero-américa, Avatares del pasado y tendencias actuales (Quilmes, 1997); Héctos Rúben Cucuzza \& Pablo Pineau, "The Histelea Project: The Social History of the Teaching of Reading and Writing in Argentina", Paedagogica Historica, XXXVI /2 (2000), pp. 677-698.

56. <http: // www.uia.ac.be / aequatoria $>$. 
projetos conjuntos, tanto regionais, quanto nacionais ou internacionais, concorrem para o desenvolvimento de pesquisas sobre a história do livro e da educação escolar. Como escreveu lan Michel há alguns anos: "Não podemos fazer muita coisa até sabermos que livros foram publicados e onde estão os volumes sobreviventes." ${ }^{57} 0$ pesquisador que trabalha com a literatura escolar se vê então dispensado de se dedicar a um trabalho prévio individual, fastidioso, cronométrico freqüentemente lacunar e, nesse sentido, dissuasivo. Por outro lado, esses instrumentos se mostram polivalentes, uma vez que, quer se atenham ao conjunto da produção nacional ou à determinada faixa cronológica ou disciplina ou nível escolar determinado, têm um caráter exaustivo e não se inscrevem em uma problemática particular. Quando as informações são geradas por programa de base de dados, eles se prestam a múltiplas funções: pesquisas sob critérios simples e múltiplos, de subgrupos "personalizados”, obtenção de índex múltiplos, análises estatísticas sobre a evolução quantitativa da oferta editorial, sobre a divisão geográfica da produção, sobre a distribuição da produção por autores e editoras, até mesmo sobre o próprio conteúdo das obras ou, em uma perspectiva lexicométrica, sobre a formulação dos títulos.

Esse esforço de acumulação, normalização e difusão das informações, que caracterizam a pesquisa sobre a história do livro e das edições escolares diz respeito também a fontes conexas, inventários de arquivos, coletânea de programas e textos oficiais. Assinalemos em particular o notável trabalho de catalogação e de análise de revistas pedagógicas efetuado ou que estão em curso em vários países: a Bélgica, que deu os primeiros passos nesse campo de pesquisa, os Países Baixos, a França, a Grécia, a Itália, Portugal, o Brasil e, em menor escala, a Alemanha e a Grã-Bretanha.

\section{Da produção à forma de consumo}

A tendência mais evidente das pesquisas desenvolvidas nos últimos vinte anos é a da extensão do campo de investigação e, nesse sentido, ocorre a diversificação das problemáticas e a multiplicação dos agentes. "0 livro didático, como observou Chris Stray, em 1993, é um produto cultural complexo... [que] se situa no cruzamento da cultura, da pedagogia, da produção editorial e da sociedade". ${ }^{58}$ Para retomar a metodologia elaborada em 1986 por Weinbrenner, podemos dizer que, sob uma perspectiva histórica, a pesquisa desenvolvida sobre o livro escolar de início dizia respeito ao próprio produto, ou seja, essencialmente ao seu conteúdo (product-oriented researches); apenas recentemente os historiadores têm se interessado pelas diversas etapas que balizam a existência de um livro (process-oriented researches), sem deixar de privilegiar algumas delas, como as reações e as críticas que podem ser suscitadas pelos livros didáticos (reception-oriented researches). ${ }^{59}$

Dentre as etapas as sucessivas da existência de um livro, a que trata da concepção, da produção e da difusão parece suscitar um interesse particular, ao menos nos países nos quais os livros didáticos são produzidos pela iniciativa privada. Se a história das edições didáticas só tem sido abordada recentemente, a despeito do peso econômico considerável do setor, é certamente porque os livros didáticos, desprezados por muito tempo pelos bibliógrafos e bibliotecários, acenderam apenas tardiamente ao status de livro. Mas é também porque encontramos muitas dificuldades, exceto talvez no período mais recente, em delimitar com exatidão esse setor de atividade. A produção escolar, em geral, coincide de maneira parcial ou apenas temporariamente, com as atividades de uma editora. Desse ponto de vista, o exemplo francês, por ter dados quantificáveis, é bastante revelador: atualmente,

57. Ian Michael, "Cultural History from School Anthologies", History of Education Society Bulletin, LIII (1994), p. 61. Do original em inglês.

58. Crhis Stray, "Quia nominor Leo: vers une sociologie historique du manuel", in: Alain Choppin, Manuels scolaires: Etats et sociétés, XIXe-XXe siècles, p.77-78.

59. Peter Weinbrenner, "Kategorien und Methoden für die Analyse wirtschafts-und sozilwissenchaftlicher Lehr-und Lernmittel", Internationale Schulbuchforschung. Zeitschrift des Georg-Eckert-Instituts, VIII/3 (1986), p. 321-337. 
dois grandes grupos, Vivendi e Hachette, dividem cerca de $80 \%$ do mercado escolar, mas suas atividades não se limitam a essa área; ao consultar o banco de dados Emmanuelle, que contabiliza a produção nacional francesa desde 1789, constata-se que a publicação de livros escolares é, para a maioria das empresas, uma atividade ocasional, por vezes marginal: metade das editoras elencadas publicou apenas um livro didático. Mas como ainda não dispomos, salvo raras exceções, da lista das produções escolares, é impossível estabelecer o conjunto da produção das editoras e, muito menos, fazer uma idéia precisa da evolução vivida por esse setor editorial.

Por esta razão as publicações sobre as editoras mais importantes ou as atividades editoriais de associações de educadores representam o setor mais abordado sobre esse tema, mas também o mais parcial e mais heterogêneo na medida em que algumas dessas publicações são provenientes das próprias empresas e tais publicações têm, nesse sentido, certa propensão em fazer obra publicitária ou hagiográfica. ${ }^{60}$ Uma prova disso é a comparação da obra, ainda que fortemente documentada, que Jean Mistler publicou em 1964 pela editora Hachette, empresa em que trabalhou em toda a sua vida, com o estudo a ela recentemente dedicado pelo historiador Jean-Yves Mollier. ${ }^{61}$ Mas, na maioria das vezes, por causa da dispersão ou do caráter lacunar ou inacessível das fontes necessárias, os trabalhos não alcançam tal amplitude e é indiretamente, ao retraçar o destino de uma obra de sucesso ou por via da biografia do fundador, que lhe dá nome ou de um autor renomado que se evoca a história da empresa.

A história particular da empresa, de sua produção, de suas estratégias financeiras ou comerciais, de suas filiais ou sucursais, de suas relações com os poderes políticos e religiosos, com o meio científico e profissional, etc. se constitui, certamente, como percurso obrigatório. Mas a história das edições escolares não pode ser reduzida a uma adição de abordagens monográficas: esse setor está submetido a uma série de determinações específicas; é tributário de um contexto político, demográfico, regulador, científico, financeiro, econômico, tecnológico, pedagógico, etc. que condiciona sua existência, sua estrutura, seu desenvolvimento e a própria natureza de suas produções. Somente uma abordagem globalizante pode apreender suas evoluções. Esta é a razão pela qual as tentativas de síntese são ainda muito raras, parciais e ainda provisórias. Mas, se o movimento iniciado por certos editores de colocar seus arquivos à disposição dos pesquisadores se confirmar e se a constituição dos instrumentos fundamentais de pesquisa prosseguir no ritmo atual, permitindo efetuar análises quantitativas e de comparação, a história da edição escolar se mostra como um dos campos mais promissores para os próximos anos. ${ }^{62}$

Ao lado do setor industrial e comercial, outros aspectos despertam, atualmente, a atenção dos historiadores tais como a relação entre o livro didático e a formação dos professores, ${ }^{63}$ os livros didáticos e sua utilização na educação não formal, ${ }^{64}$ a linguagem utilizada pelos livros didáticos, ${ }^{65}$ o perfil sociológico dos

60. Nesse sentido se explica que uma das raras publicações efetuadas na Coréia, sobre a história dos livros didáticos, tome como principal objeto de estudo a principal editora nacional de livros didáticos: Chong Kuk Lee, Te Han Kyo Kwa So, 1948 -1998 (Seul, 1998).

61. Jean Mistler, La Librairie Hachette de 1826 até à nos jours (Paris, 1964); Jean-Yves Mollier, Louis Hachette (Paris, 1999).

62. Vários trabalhos estão em andamento, notadamente na Espanha, no Brasil, no México, mas é certamente na Itália, no círculo de Giorgio Chiosso, e na França, de um lado, no Departamento de História da Educação e, de outro, no Centro de História Cultural dirigido por Jean-Yves Mollier, na Universidade de Verssailles-Saint-Quentin-en-Yvelines, que se desenvolvem as investigações mais sistemáticas.

63. Teresa Rabazas Romero, Los manuales de pedagogía y la formación del profesorado en las escuelas normales de España, 1839-1901 (Madri, 2001). 64. Por exemplo: Maria Stephanou, "Práticas formativas da medicina: manuais de saúde e a formação da urbanidade", in: Julieta Beatriz Ramos Desaulniers (Org.), Formação e cidadão e cidadania, Veritas, 43 (1998), p.141-150.

65. Por exemplo: William E. Marsden, "The Language of Geography Textbook: an historical appraisal", Westminster Studies in Education, II (1979); Paul Bruthiaux, "Knowing when to stop: investigating the nature of punctuation", Language \&Communication, XIII/1 (1993), p. 27-43; Brian Dolan, "The Language of Experiment in Chemical Textbooks: some examples from early nineteenth-century Britain", in Anders Lundgren \& Bernadette Bensaude-Vincent (eds.), Communicating Chemistry: textbooks and their audience, 1789-1939 (Canton, 2000), p. 141-164. 
autores, ${ }^{66}$ o papel das mulheres na elaboração e difusão dos saberes escolares, ${ }^{67}$ etc.

Um interesse particular vem sendo dado, de uns vinte anos para cá, às questões referentes ao uso e à recepção do livro didático. Que tipo de consumo se faz deles? Os educadores os seguem fielmente, passo a passo, ou tomam certas liberdades em relação à organização que eles propõem? E, nesse caso, quais e por quais razões? Como o aluno lê seu livro escolar, em voz alta, em silêncio? Ele o relê, em classe, em casa? O livro serve de consulta ou serve para “decoração" da matéria? Quanto tempo o aluno passa com seus livros? Qual a real influência exercida pelos livros didáticos sobre o comportamento das crianças e sobre o comportamento social em geral? Essa influência, que até bem pouco tempo era admitida como indubitável, foi questionada no início dos anos 1980, e várias pesquisas recentes levaram a relativizar sua importância. $^{68}$

Considerando-se ainda seu papel na sociedade, quais opiniões, reações, críticas os livros didáticos suscitam entre seus contemporâneos, governo, educadores, pais, comunidade científica, etc. Desse ponto de vista, os livros didáticos produziram uma literatura crítica extremamente abundante: imprensa, revistas pedagógicas, correspondência oficial oferecem um corpus de textos ainda subexplorados. ${ }^{69}$

\section{A dimensão transnacional: influências e empréstimos}

A última tendência marcante que poderia caracterizar a pesquisa recente sobre a história do livro e as edições escolares é a consideração de sua dimensão transnacional. A reivindicação do princípio do caráter nacional ou regional - da literatura escolar moderna que se inscreve, tanto hoje quanto em passado recente, na afirmação de uma identidade cultural, não consegue mascarar as várias influências e trocas ocorridas. Por meio da evangelização, da colonização ou da alfabetização em massa, os modelos nacionais são exportados e difun- didos no exterior. De uns dez anos para cá, as questões relativas à utilização, à tradução, à adaptação de livros didáticos "exógenos" foram objeto de numerosos estudos, tanto na Grécia quanto na Itália, na Argentina, no Brasil, Chile, México, Quebec e em muitos outros países. ${ }^{70}$ Essas pesquisas, ao tratarem da emergência de uma literatura escolar nacional, ou do processo vivido pelos best-sellers como o Giannetto, de Luigi Alessandro Parravicini, o Cuore, de Edmondo De Amicis (que foi traduzido em 25 linguas), Le tour de la France par deux enfants, de G. Bruno, e tantos outros, são ainda muito pontuais para que possamos tirar delas conclusões mais gerais.

Do mesmo modo, ainda que as pesquisas em curso mostrem que sua influência não deve ser superestimada, as publicações estrangeiras, importadas ou traduzidas, que são destinadas à formação de educadores (obras de pedagogia geral, revistas pedagógicas, etc.), são testemunhos da circulação de conteúdos de ensino e métodos pedagógicos. Alguns trabalhos estudam o papel desempenhado por associações de educadores na produção e difusão em grande parte do universo das edições genéricas adaptadas às populações locais $;^{71}$ outras

66. Christina Koulouri, Dimensions idéologiques de l'historicité em Gréce (1834-1914). Les manuels scolaires d'histoire et de géographie (Frankfurt am Main, 1988).

67. Pilar Ballarín Domingo, Angela Caballero, Consuelo Flecha \& Mercedes Vico, "Maestras y libros escolares", in: Alejandro Tiana Ferrer (Dir.), Reflejo de intenciones políticas e influencias pedagógicas (Madrid, 2000), p. 341-375.

68. Henri Moniot, na França, e Rainer Riemenschneider, na Alemanha, vêm, desde 1984, demonstrando a influência, até então apenas suposta, dos livros didáticos na formação das mentalidades. Uma das contribuições mais importantes a esse respeito é a de Cristophe Caritey, "Manuels scolaires et mémoire historique au Québec: questions de méthodes", in: Alain Choppin (Dir.), Manuels scolaires: Etats et sociétés, XIXe-XXe siècles, p. 137-164. 69. Destacamos, a respeito desse último aspecto o trabalho pioneiro de Paul Aubin \& Michel Simard, Les manuels scolaires dans la correspondance du Département de l'instruction publique, 1842-1899: inventaire (Sherbrooke, 1997).

70. Referimo-nos, entre outros, aos trabalhos de Christina Koulouri, na Grécia; de Mariella Rigotti Colin, de Carla Pellandra e de Nadia Minerva, na Itália; de Clara Brafman, na Argentina; de Wagner Rodrigues Valente e de Maria Helena Câmara Bastos, no Brasil; de Juan Pablo Conjeneros Maldonado, no Chile; de Lucía Martinez Moctezuma, no México; de Paul Aubin, de Serge Gagnon e de Thérèse Hamel, em Quebec.

71. Paul Aubin, Les communautés religieuses et l'édition au Québec, 1765-1964 (Sherbrooke, 2001). 
se interessam pela implantação e pelo desenvolvimento de sucursais ou filiais de editoras estrangeiras, notadamente na América Latina (no Brasil, no México ou na Argentina principalmente) ou nos territórios anteriormente administrados pela Grã Bretanha ou pela França. ${ }^{72}$

Sendo assim, ao fazer parte da constituição e da difusão de mitos fundadores ou ao experimentar novos métodos de aprendizagem, a edição escolar adota, recupera, adapta e rejeita modelos estrangeiros ou, em uma perspectiva mais imperialista, como na África francofônica, por exemplo, os impõe. Também se desenvolvem as pesquisas que tratam da circulação de idéias e de capitais culturais, uma vez que se situam no coração da compreensão dos mecanismos que concorrem para a elaboração da identidade cultural.

\section{***}

Este estudo, embora resumido e ainda incompleto, permite destacar algumas importantes transformações que caracterizaram a pesquisa histórica sobre o livro e as edições didáticas a partir dos anos 1960. Constata-se:

- uma mudança de perspectiva, inicialmente: os livros didáticos eram estudados - e em muitos casos continuam sendo - como vetores ideológicos e culturais, sem serem abordados como instrumentos pedagógicos e didáticos, ou como produtos manufaturados, comercializados e consumidos;

- uma mudança de método, em seguida: sem substituir as investigações particulares, limitadas e freqüentemente empíricas, desenvolvem-se cada vez mais programas coletivos de pesquisa, de abrangência nacional ou internacional, que visam acumular e difundir informações;

- uma mudança de escala, por fim: por muito tempo confinada dentro das fronteiras nacionais, a pesquisa sobre o livro didático abriu-se para novas dimensões, de um lado, ao levar em conta especificidades regionais e estabelecer relações com as influências estrangeiras.
Paralelamente, desenvolveu-se, nos últimos vinte anos, uma intensa reflexão de natureza metodológica que suscitou abundante literatura; dinamismo que também se manifesta em inúmeras trocas e colóquios.

Essas transformações são, no entanto, mais ou menos marcantes, mais ou menos recentes, em ritmos diversos que dependem das características geográficas e culturais. Há particularidades que estão ligadas a tradições (notamos um interesse mais marcante pelos conteúdos ideológicos na Alemanha, no Japão ou na França, pelos aspectos econômicos e comerciais no mundo anglo-saxão, etc.) ou que refletem interesses contemporâneos. Essas particularidades nacionais influem na natureza, nas funções e usos dos livros didáticos e também sobre o próprio modo pelo qual a historiografia nacional os apreende. Se não é possível avançar mais nessa reflexão, é porque não dispomos de obras de síntese ou levantamentos quantitativos em escala nacional ou regional. Com efeito, ainda são raros os países que possuem um inventário, ainda que sumário, sobre o que foi publicado a respeito da pesquisa da história e a literatura escolar.

Tais instrumentos, que reuniriam as produções científicas nacionais (e delas dariam um breve resumo), apresentariam, no entanto, muitos benefícios: evitariam que pesquisadores e estudantes tivessem de desenvolver trabalhos redundantes e, portanto, quase sempre inúteis; a consulta a seus índex permitira esboçar periodicamente o estado da arte da pesquisa nacional e destacar as áreas ainda pouco abordadas; e, finalmente, tais centros de referência favoreceriam e facilitariam os estudos comparativos em um campo de pesquisa no qual, ainda que possa parecer paradoxal, as trocas, os empréstimos e as influências são essenciais, tanto no plano da cultura quanto no da economia.

72. Por exemplo: J. A. Mangan (Ed.), The Imperial Curriculum. Racial Images and Education in the British Colonial Experience (New York, 1993); Jean-François Botrel, "L'exportation des livres et modèles éditoriaux français en Espagne et en Amérique latine", in: Jacques Michion \& JeanYves Mollier, Les mutations du livre, p. 217-240; Claudia Schulz, "Construire le paysage de l'édition dans l'Afrique 'francophone' de l'Ouest durant l'époque post-coloniale", ibid., p. 241-250. 